\title{
Effect of Different Age of Rootstocks on Success of Softwood Grafting Technique in Tamarind (Tamarindus indica L.) under Northern Dry Zone of Karnataka
}

\author{
Arif A. Agasimani ${ }^{1}$ *, G. S. K. Swamy ${ }^{2}$, Nagesha Naik ${ }^{3}$, R.C. Jagadeesha ${ }^{4}$, \\ P.M. Gangadharappa ${ }^{5}$ and N. Thammaiah ${ }^{6}$ \\ ${ }^{1}$ Department of Horticulture, Lalbagh, Bengaluru - 560 004, Karnataka, India \\ ${ }^{2}$ Department of Fruit Science, $\mathrm{COH}$, Mysuru, Karnataka, India \\ ${ }^{3}$ K. R. C. College of Horticulture, Arabhavi-591 218, Karnataka, India \\ ${ }^{4}$ UHS, Bagalkot - 587 104, Karnataka, India \\ ${ }^{5}$ College of Horticulture, Munirabad, Karnataka, India \\ ${ }^{6}$ Department of HPP, COH, Mysuru, Karnataka, India
}

*Corresponding author

\begin{tabular}{|c|c|}
\hline & A B S T R A C T \\
\hline $\begin{array}{l}\text { Ke y w o r d s } \\
\text { Tamarind } \\
\text { (Tamarindus } \\
\text { indica L.), DAG, } \\
\text { Per cent Sprouting }\end{array}$ & \multirow{3}{*}{$\begin{array}{l}\text { An experiment was conducted on effect of different age of rootstocks on success } \\
\text { of softwood grafting in tamarind. Higher percentage of graft success }(70.39 \%) \text {, } \\
\text { grafts survivability }(70.95 \%) \text {, sprouting per cent }(14.40 \%) \text {, minimum days taken } \\
\text { for sprouting }(12.52) \text { and number of sprouts }(7.23) \text { were noticed in } \mathrm{T}_{7}(6 \mathrm{month} \\
\text { old rootstocks). The maximum graft height }(37.31 \mathrm{~cm}) \text {, graft diameter }(7.92 \mathrm{~mm}) \text {, } \\
\text { length of sprouts }(19.02 \mathrm{~cm}) \text { and number of leaves }(41.35) \text { were noticed in } \mathrm{T}_{7} \text {. } \\
\text { Study revealed that, softwood grafting in April and May on } 6 \text { month old } \\
\text { rootstocks might be followed for multiplication of elite tamarind trees with high } \\
\text { graft success. }\end{array}$} \\
\hline Article Info & \\
\hline $\begin{array}{l}\text { Accepted: } \\
\text { 07 March } 2019 \\
\text { Available Online: } \\
10 \text { April } 2019\end{array}$ & \\
\hline
\end{tabular}

Introduction

Tamarind (Tamarindus indica L.) is a monotypic genus tree belonging to the family Leguminosae, sub-family caesalpiniaceae with somatic chromosome number of $2 \mathrm{n}=24$ (Purseglove et al., 1987). It is indigenous to Tropical Africa and Southern India (Nas,
1979). India exports processed tamarind pulp to western countries mainly European and Arab countries and more recently the USA (Rao and Mathew, 2012). It is estimated that India produces an annual production of pulp over 1.99 lakh tones and exported the tamarind products worth of rupees 57 crores per annum during 2017-18 (Anon., 2017). It 
is highly heterozygous, cross-pollinated fruit crop and as such seedlings exhibit a wide range of variations, which aids in the selection of the superior desirable genotypes. Due to cross pollination and predominant practice of seed propagation, there is immense opportunity to locate elite trees having desirable horticultural traits, which needs to be conserved and exploited (Keskar et al., 1989; Pathak et al.,1992; Karale et al., 1999). Despite its varied advantages, it could not attract suitable scientific attention towards its propagation. True-to-the-type propagules could be multiplied from elite trees that produce good quality fruits only by asexual methods. Of various propagation methods, grafting is of paramount importance in tropical and subtropical fruit trees as they result in high success and field establishment. Therefore, the present investigation was undertaken to study the effect of different age of rootstock on success of softwood grafting under Northern dry zone of Karnataka.

\section{Materials and Methods}

The investigation was carried out at K. R. C. College of Horticulture, Arabhavi, Karnataka, India during the year 2018. The locally available seeds of tamarind (Belagavi region) were sown in the polythene bags filled with sand, soil and FYM (1:1:1) for raising the rootstocks. Irrigation, weeding and other desired intercultural operations were done as and when required. About 1-12 months old seedlings of uniform size having stem of pencil thickness were used as rootstock. Softwood grafting was carried out at March and April month of 2018 and data were recorded. Scion shoots of promising genotype (DTS-2) having desirable horticultural traits was used to perform the grafting. The experiment was laid out in completely randomized block design with three replications and 10 plants in each replication as unit. Data on days taken for sprouting, number of sprouts, sprouting per cent were recorded soon after bud burst while success per cent and survivability of grafts were recorded 3 months after grafting. Graft height $(\mathrm{cm})$, graft diameter $(\mathrm{mm})$, sprout length $(\mathrm{cm})$ and number of leaves were recorded at an interval of 30, 60 and 90 days after grafting.

\section{Results and Discussion}

The perusal of the data presented in Table 1 reveals that days required for bud sprouting differed significantly due to different aged rootstocks used for softwood grafting. It was observed that the $\mathrm{T}_{7}$ (6 months) took significantly minimum number of days for sprouts (12.52), maximum number of sprouts (7.23) and sprouting percentage (14.40\%). Higher temperature during March-April has helped in early sprouting which may be due to fast establishment of vascular connection in rootstock and scion as has been reported by Satishkumar (2001), Ganachary (2005), Veeresh (2006), Giri and Lenka (2007), Singh and Singh (2007). The success in bud sprouting was affected significantly by time of propagation (Table 1 and 2). The highest sprouting was recorded when softwood grafting was done in March and April month, closely followed by May. Least sprouting was recorded in $\mathrm{T}_{12}$ (1 month). Similarly, per cent success also showed significant variation when grafting was done on April month. This finding is in agreement with the findings of Purushotham and Narasimharao (1990), Shinde et al., (1996), Satisha et al., (1997), Kulwal et al., (1997), Nachegouda (1997), Bodkhe and Lalan (2010), Bharad and Mahorkar (2011). The best results in sprouting and success in March, April and May month may be due to optimum temperature and relative humidity prevailing during this period resulting in early contact of cambium layers of stock and scion, early callus formation and initiation of subsequent growth. 
Table.1 Effect of age of rootstock on percent graft success, sprouting percentage, days taken for sprouting, number of sprouts, graft height, graft diameter, sprout length and number of leaves in softwood grafting of tamarind during 2018

\begin{tabular}{|c|c|c|c|c|c|c|c|c|c|c|c|c|c|c|c|c|c|}
\hline \multirow[t]{2}{*}{ Treatment } & \multirow[t]{2}{*}{$\begin{array}{c}\text { Age of } \\
\text { rootstock }\end{array}$} & \multirow{2}{*}{\begin{tabular}{|c|}
$\begin{array}{c}\text { Per } \\
\text { cent } \\
\text { graft } \\
\text { success }\end{array}$ \\
\end{tabular}} & \multirow[t]{2}{*}{$\begin{array}{l}\text { Sprouting } \\
\text { percentage }\end{array}$} & \multirow{2}{*}{\begin{tabular}{|c|} 
Days \\
taken for \\
sprouting
\end{tabular}} & \multirow{2}{*}{$\begin{array}{l}\text { Number } \\
\text { of } \\
\text { sprouts }\end{array}$} & \multicolumn{3}{|c|}{$\begin{array}{l}\text { Graft height } \\
\text { (cm) }\end{array}$} & \multicolumn{3}{|c|}{$\begin{array}{c}\text { Graft diameter } \\
(\mathbf{m m})\end{array}$} & \multicolumn{3}{|c|}{$\begin{array}{c}\text { Sprout length } \\
(\mathrm{cm})\end{array}$} & \multicolumn{3}{|c|}{ Number of leaves } \\
\hline & & & & & & \begin{tabular}{|c|} 
30 \\
DAG
\end{tabular} & $\begin{array}{c}60 \\
\text { DAG }\end{array}$ & $\begin{array}{c}90 \\
\text { DAG }\end{array}$ & $\begin{array}{c}30 \\
\text { DAG }\end{array}$ & $\begin{array}{c}\text { 60 } \\
\text { DAG }\end{array}$ & $\begin{array}{c}90 \\
\text { DAG }\end{array}$ & $\begin{array}{c}\text { 30 } \\
\text { DAG }\end{array}$ & $\begin{array}{c}60 \\
\text { DAG }\end{array}$ & $\begin{array}{c}90 \\
\text { DAG }\end{array}$ & $\begin{array}{c}\text { 30 } \\
\text { DAG }\end{array}$ & $\begin{array}{c}\text { 60 } \\
\text { DAG }\end{array}$ & $\begin{array}{c}90 \\
\text { DAG }\end{array}$ \\
\hline $\mathbf{T}_{1}$ & 12 months & 33.43 & 6.66 & 14.35 & 3.33 & 5.10 & 19.69 & 24.71 & 2.06 & 3.50 & 4.31 & 2.51 & 6.62 & 10.93 & 3.94 & 24.00 & 31.20 \\
\hline $\mathbf{T}_{2}$ & 11 months & 28.40 & 12.67 & 15.26 & 6.23 & 6.06 & 19.26 & 22.11 & 2.11 & 3.56 & 3.80 & 2.07 & 5.88 & 10.69 & 2.74 & 15.28 & 29.53 \\
\hline $\mathbf{T}_{3}$ & 10 months & 36.69 & 12.50 & 16.04 & 6.25 & 6.66 & 21.59 & 24.14 & 2.54 & 3.92 & 4.20 & 2.48 & 5.76 & 12.21 & 3.77 & 16.61 & 1.93 \\
\hline $\mathbf{T}_{4}$ & 9 months & 29.06 & 9.47 & 17.55 & 4.77 & 8.44 & 22.81 & 27.89 & 3.65 & 5.27 & 5.48 & 2.25 & 6.62 & 14.37 & 3.43 & 19.67 & 3.04 \\
\hline $\mathbf{T}_{5}$ & 8 months & 42.37 & 12.53 & 13.05 & 6.27 & 9.25 & 25.77 & 31.21 & 4.15 & 6.30 & 6.52 & 2.67 & 8.16 & 16.17 & 3.55 & 25.41 & 33.87 \\
\hline $\mathbf{T}_{6}$ & 7 months & 60.31 & & 12.73 & & 11.18 & 29.09 & 32.37 & 5.14 & 7.16 & 7.32 & 2.79 & 8.33 & 18.47 & 4.74 & 34.04 & 7.47 \\
\hline $\mathbf{T}_{7}$ & 6 months & 70.39 & 14.40 & 12.52 & 7.23 & 13.16 & 31.35 & 37.31 & 5.63 & 7.83 & 7.92 & 3.01 & 9.42 & 19.02 & 4.75 & 40.80 & 41.35 \\
\hline $\mathbf{T}_{8}$ & 5 months & 69.48 & 13.20 & 19.70 & 6.67 & 7.02 & 25.38 & 32.48 & 4.11 & 6.54 & 6.79 & 1.86 & 6.68 & 14.66 & 3.41 & 27.40 & 29.30 \\
\hline $\mathbf{T}_{9}$ & 4 months & 33.90 & 5.47 & 22.52 & 2.73 & 5.17 & 19.89 & 25.18 & 3.03 & 6.16 & 6.24 & 1.59 & 6.09 & 7.92 & 3.08 & 30.00 & 30.40 \\
\hline$T_{10}$ & 3 months & 30.59 & 4.80 & 22.91 & 2.40 & 4.76 & 15.97 & 18.71 & 2.13 & 5.78 & 6.19 & 1.68 & 4.99 & 6.05 & 2.74 & 18.71 & 22.33 \\
\hline $\mathbf{T}_{11}$ & 2 months & 26.35 & 3.67 & 24.33 & 2.03 & 4.67 & 14.18 & 18.09 & 1.89 & 4.59 & 5.55 & 1.64 & 4.25 & 5.73 & 2.53 & 11.87 & 16.88 \\
\hline \multirow[t]{5}{*}{$\mathbf{T}_{12}$} & 1months & 20.71 & 2.13 & 25.94 & 1.07 & 4.34 & 11.45 & 14.32 & 1.73 & 3.18 & 4.07 & 1.33 & 3.74 & 5.54 & 2.00 & 8.80 & 15.61 \\
\hline & Mean & 40.14 & 9.14 & 18.07 & 4.61 & 7.15 & 21.37 & 25.71 & 3.18 & 5.32 & 5.70 & 2.16 & 6.38 & 11.81 & 3.39 & 22.72 & 29.41 \\
\hline & S.Em \pm & 1.31 & 0.60 & 0.41 & 0.28 & 0.35 & 0.58 & 0.82 & 0.29 & 0.17 & 0.17 & 0.19 & 0.45 & 0.50 & 0.30 & 1.72 & 1.03 \\
\hline & $\begin{array}{l}\text { CD } \\
0.01\end{array}$ & 5.19 & 2.40 & 1.63 & 1.13 & 1.39 & 2.30 & 3.25 & 1.14 & 0.67 & 0.68 & 0.76 & 1.79 & 2.01 & 1.22 & 6.80 & 4.07 \\
\hline & CV (\%) & 5.66 & 11.52 & 3.94 & 10.74 & 8.55 & 4.72 & 5.54 & 15.79 & 5.58 & 5.28 & 15.47 & 12.30 & 7.47 & 15.77 & 13.12 & 6.06 \\
\hline
\end{tabular}


Table.2 Effect of age of rootstock on grafts survival in softwood grafting of tamarind genotypes during 2018

\begin{tabular}{|c|c|c|}
\hline Treatment & Age of rootstock & Graft survival (\%) \\
\cline { 2 - 3 } & & $\mathbf{2 0 1 8}$ \\
\hline $\mathbf{T}_{\mathbf{1}}$ & 12 months & 31.09 \\
\hline $\mathbf{T}_{\mathbf{2}}$ & 11 months & 30.69 \\
\hline $\mathbf{T}_{\mathbf{3}}$ & 10 months & 39.57 \\
\hline $\mathbf{T}_{\mathbf{4}}$ & 9 months & 30.83 \\
\hline $\mathbf{T}_{\mathbf{5}}$ & 8 months & 38.96 \\
\hline $\mathbf{T}_{\mathbf{6}}$ & 7 months & 62.92 \\
\hline $\mathbf{T}_{\mathbf{7}}$ & 6 months & 70.95 \\
\hline $\mathbf{T}_{\mathbf{8}}$ & 5 months & 60.83 \\
\hline $\mathbf{T}_{\mathbf{9}}$ & 4 months & 38.77 \\
\hline $\mathbf{T}_{\mathbf{1 0}}$ & 3 months & 31.11 \\
\hline $\mathbf{T}_{\mathbf{1 1}}$ & 2 months & 28.91 \\
\hline $\mathbf{T}_{\mathbf{1 2}}$ & 1 months & 27.03 \\
\hline & Mean & $\mathbf{4 0 . 9 7}$ \\
\hline & S.Em \pm & 0.36 \\
\hline & CD 0.01 & 1.42 \\
\hline & CV $(\%)$ & 1.52 \\
\hline
\end{tabular}

At the final observation (90 Days after grafting), the data revealed significant variation in graft height $(\mathrm{cm})$, graft diameter $(\mathrm{mm})$, length of sprout $(\mathrm{cm})$ number of leaves that ranged between 14.32 to $37.31 \mathrm{~cm}, 4.07$ to $7.92 \mathrm{~mm}, 5.54$ to $19.02 \mathrm{~cm}$ and 15.61 to 41.35, respectively (Table 1).

Maximum graft height, length of sprouts, diameter of grafts and number of leaves were recorded in May month. The quick and strong union formation, better nutrient uptake and ample growing period might have caused better plant growth and more number of leaves per plant in April and May.

Awasthi and Shukla (2003), Giri and Lenka (2007), Singh and Singh (2007) recorded similar findings in tamarind under different agro-climatic conditions. Therefore, softwood grafting in April and May month may be followed for multiplication of elite tamarind trees with high graft success rate.

\section{References}

Anonymous, 2017, Area and production of spices in India. Spices Board, Cochin, Kerala.

Awasthi, O. P. and Shukla, N. 2003, Effect of time on success of soft wood grafting in tamarind (Tamarindus indica L.). Range Mangt. Agro-forestry, 24: 31-34

Bharad, S. and Mahorkar, V., 2011, Softwood grafting as useful method of propagation for commercial multiplication of Syzygium cuminii L. under semi-arid climatic conditions of India. Acta Hort., 890: 230-234.

Bodkhe, V. A. and Lalan, V. R., 2010, Propagation studies in jamun. Int. J. Agric. Sci., 6 (1): 250-252.

Ganachary, V., (2005), Evaluation and propagation of tamarind genotypes. M.Sc. (Hort.) Thesis, University of Agricultural Sciences, Dharwad.

Giri, B. and Lenka, P. C., 2007, Propagation 
of tamarind (Tamarindus indica L.) through softwood grafting. Indian Forester, 18 (2): 1133-1135.

Karale, A. R., Wagh, A. P., Pawar, B. G. and More, T. A. 1999, Association of fruit characters in tamarind. J. Maharashtra Agril. Univ. 24(3): 19-20.

Keskar, B. G., Karale, A. R., Dhawale, B. C. and Chaudhary, K. G. 1989, Improvement of tamarind by selection. Maharashtra J. Hort. 4: 121-24.

Kulwal, U., Tayde, G. S., Chaudari, M. H. and Verma, 1997, An easy method of propagation of tamarind. Proceedings of National Symposium on Tamarindus indica L., Tirupathi, Andhra Pradesh, 27-28 June, 1997, pp. 94-97.

Nachegouda, V., 1997, Propagation of tamarind by layering and greenwood cleft grafting. Proceedings of National Symposium on Tamarindus indica, Tirupathi, Andhra Pradesh, 27-28 June, 1997, pp. 89-93.

Nas, S., 1979, In: Tropical Legumes: Resources for the Future, Washington DC, pp.117-121.

Pathak, R. K., Ojha, C. M. and Dwivedi, R. 1992, Adopt patch budding for quicker multiplication in tamarind.

Purseglove, J. W. 1987, Tropical crops. Dicotyledons, Longuma. Science and Technology, pp. 204-206.
Purushotham, K. and Narasimharao, S. B. S., 1990, Propagation of tamarind by veneer and softwood grafting. South Indian Horticulture, 38: 225.

Rao, Y. S. and Mathew, K. M., 2012, Tamarind (Tamarindus indica L.).Wood head publishing limited, England. pp, $512-533$.

Satishkumar, V., 2001, Studies on wedge grafting in tamarind (Tamarindus indica L.). M. Sc. (Agri.) Thesis. University of Agriculture Sciences, Dharwad.

Satisha, J., Melanta, K. R. and Venkatesha, J., 1997, Effect of age of rootstock on success of softwood grafting in tamarind. Current Research, 26 (6-7): 93-94.

Singh, S. and Singh, A. K., 2007, Standardization of method and time of vegetative propagation in tamarind under semi-arid environment of western India. Indian. J. Hort., 64(1): 45-49.

Shinde, N. N., Ingle, G. N. and Shirurkar, D. D., 1996, Softwood grafting in tamarind (Tamarindus indica L.). Journal of Applied Horticulture, 2(1): 139-142.

Veeresh, K., 2006, Evaluation, propagation and processing of tamarind (Tamarindus indica L.). M.Sc. (Hort.) Thesis, University of Agricultural Sciences, Dharwad.

\section{How to cite this article:}

Arif A. Agasimani, G. S. K. Swamy, Nagesha Naik, R.C. Jagadeesha, P.M. Gangadharappa and Thammaiah, N. 2019. Effect of Different Age of Rootstocks on Success of Softwood Grafting Technique in Tamarind (Tamarindus indica L.) under Northern Dry Zone of Karnataka. Int.J.Curr.Microbiol.App.Sci. 8(04): 562-566. doi: https://doi.org/10.20546/ijcmas.2019.804.060 